\title{
Evaluation of Cytomegalo Virus Seropositivity in Haemodialysis Patients and its Relation to Metabolic Syndrome George Emad Shaker ${ }^{1}$, Heba Shafe ak Abd El Khalik ${ }^{1}$, Rehab Ahmed Rabie ${ }^{2}$ , Ramy Wagdy Ahmed Abd ElAziz ${ }^{1}$ \\ Departments of ${ }^{1}$ Internal Medicine and ${ }^{2}$ Medical Microbiology and Immunology, Faculty of Medicine - Zagazig University, Egypt
}

\section{ABSTRACT}

Background: Chronic haemodialysis patients are at high risk for infection because the process of haemodialysis (HM) requires vascular access for prolonged periods. The human Cytomegalo Virus (CMV) is a DNA virus belonging to the Herpesviridae family, Betaherpsvirnae subfamily and Cytomegalo virus gender, known as Human Herpes Virus Type 5, one of the main causes of morbidity. Acute CMV infection is characterized by system-wide viremia after which latency and lifelong persistence is established in selected cells such as CD34+ monocytes and hematopoietic progenitor cells in humans.

Objective: The work was designed for early detection of CMV infection and metabolic syndrome (MetS) in patients on HD.

Patients and Methods: In this cross-sectional study, 80 patients under regular HD due to end-stage renal disease (ESRD) had participated in the study from HD Unite of Nasr City Health Insurance Hospital in Cairo in the period from June 2019 to December 2019.

Results: In the present study, patients were divided into three groups, first group 78 patients were positive for CMV IgG (97.5\%), second group 11 patients were positive for CMV IgM (13.8\%) and third group 10 patients were positive for both IgG and IgM (12.3\%). In our study the females have more CMV antibodies. In the present study, patients with metabolic syndrome were 68 (85\%). Patients who had MetS and CMV IgG were 68 (100\%). The relationship between MetS and CMV IgG is statistically proved.

Conclusion: the importance of early investigation for metabolic syndrome components especially in patients who are immunocompromised like HD patients because of the high prevalence of both chronic CMV infection and reactivation. Keywords: Metabolic syndrome, Haemodialysis, Cytomegalo virus, Evaluation.

\section{INTRODUCTION}

The number of patients with end-stage renal disease treated by maintenance haemodialysis has increased sharply during the last 30 years. Chronic haemodialysis patients are at high risk for infection because the process of haemodialysis requires vascular access for prolonged periods. In an environment where multiple patients receive dialysis concurrently, repeated opportunities exist for person-to-person transmission of infectious agents, directly or indirectly via contaminated devices, equipment, environmental surfaces or hands of personnel ${ }^{(1)}$.

The human CMV is a DNA virus belonging to the Herpesviridae family, Betaherpsvirnae subfamily and Cytomegalo virus gender, known as Human Herpes Virus Type 5, one of the main causes of morbidity. Acute CMV infection is characterized by system-wide viremia after which latency and lifelong persistence is established in selected cells such as CD34+ monocytes and hematopoietic progenitor cells in humans (2). Although CMV infections are generally asymptomatic, untreated infections in utero or amongst the immunocompromised individuals can result in substantial developmental defects, pathology, and death (3).

However, in immunocompetent patients the substantial and varied $\mathrm{NK}, \mathrm{CD} 8, \mathrm{CD} 4$, and B cells resources are mobilized to successfully control viral spread and reactivation. One well described arm of antiCMV immunity, the CD8 T cell compartment, is heavily involved in viral control with up to $5-10 \%$ of total CD8s in the blood and secondary lymphoid tissues reactive to CMV antigens during a primary immune response ${ }^{(4)}$. It has become clear that the blood contains a major pool of CMV-reactive $\mathrm{T}$ effector memory (TEM) cells that presumably scan the vasculature as a bulwark against systemic CMV reactivation and that accumulate with age ${ }^{(5)}$.

Metabolic syndrome (syndrome $\mathrm{X}$, insulin resistance) is a multiplex risk factor that arises from insulin resistance accompanying abnormal adipose deposition and function ${ }^{(6)}$. It is a risk factor for coronary heart disease, as well as diabetes, fatty liver, and several cancers. The clinical manifestations of this syndrome may include hypertension, hyperglycaemia, hypertriglyceridemia, reduced high-density lipoprotein cholesterol (HDL-C), and abdominal obesity ${ }^{(7)}$.

The work was designed for early detection of CMV infection and metabolic syndrome in patients on HD.

\section{PATIENTS AND METHODS}

In this study a total of 80 patients who were under regular hemodialysis due to ESRD, were evaluated for CMV antibodies and metabolic syndrome components. The study involved patients of HD unite from Nasr city health insurance hospital in Cairo in the period from 
June 2019 to December 2019. After their consent, full history taking and examination were done. All patients were tested for: Total lipid profile, fasting plasma glucose level, CRP, CMV Igm and IgG using ELISA. All patients were screened and evaluated for components of metabolic syndrome by AHA/NHLBI guidelines and IDF cut points for middle east to measure $\mathrm{WC}^{(8)}$.

\section{CMV IgM ELISA kit:}

Sample preparation: Five $\mathrm{ml}$ venous blood was withdrawn from each patient in a sterile vacutainer tube containing heparin as anticoagulant. Plasma was separated and stored at $-40{ }^{\circ} \mathrm{C}$ to detect CMV IgG using ELISA technique.

Technique: Bio Tina GmbH CMV- IgM semiquantitative is a micro-well sandwich ELISA. The wells were coated with partially purified CMV antigens. The reference standard and test samples were incubated in the wells first, after incubation, the anti-CMV antibodies will bind with coated antigens and enzyme conjugate goat antihuman IgM chemically. Horseradish Peroxidase (HRP)-conjugate was then added to bind immunologically to antigen bind complex on the solid phase. Unbound enzyme conjugate was washed off. Then, substrate and chromogen were added. The intensity of color developed was proportional to the concentration of anti-CMV IgM in reference standards and test samples and quantified by use of a photometric well reader at $450 \mathrm{~nm}$ wavelength ${ }^{(9)}$.

\section{CMV IgG ELISA kit:}

Sample preparation: Five $\mathrm{ml}$ venous blood was withdrawn from each patient in a sterile vacutainer tube containing heparin as anticoagulant. Plasma was separated and stored at $-40{ }^{\circ} \mathrm{C}$ to detect CMV IgG using ELISA technique.

Technique: Purified CMV antigen was coated on the surface micro-well. Diluted patients' samples were added to the wells and the CMV IgG specific antibody, if present binds to antigen. All unbound materials were washed away. HRP-conjugate was added, which binds to the antigen-antibody complex. Excess HRPconjugate was washed off and a solution of TMP reagent was added. The enzyme conjugate catalytic reaction was stopped at specific time. The intensity of color developed was proportional to the concentration of anti-CMV IgG in the sample. The results were read by a micro-well reader compared in a parallel manner with calibrators and controls ${ }^{(9)}$.

\section{AHA/NHLBI guidelines and IDF cut points.}

To say that patient have metabolic syndrome he should have any three components of:

1. Obesity: Alberti et al. ${ }^{\left({ }^{(8)}\right.}$ recommended that the best way to confirm that patient is obese is by measuring waist circumference according to population and country specific IDF cut points. Male $\geq 94 \mathrm{~cm}$ and female $\geq 80 \mathrm{~cm}$. We used BMI as indicator for obesity too; we divided the patients according to BMI measures to 3 groups: Normal weight BMI 18.5 to 24.9, overweight BMI 25 to 29.9, and obese BMI 30 and above.

2. Elevated triglycerides $\mathrm{TG} \geq 150 \mathrm{mg} / \mathrm{dl}$ or treatment for this lipid abnormality.

3. Decreased HDL level $\leq 40 \mathrm{mg} / \mathrm{dl}$ in males or $\leq 50$ $\mathrm{mg} / \mathrm{dl}$ in females or specific treatment for this lipid abnormality.

4. Hypertension BP $\geq 130 / 85 \mathrm{mmhg}$ or taking medication for hypertension.

5. Hyperglycemia fasting plasma glucose level $\geq 100$ $\mathrm{mg} / \mathrm{dl}$ or taking diabetes treatment.

So, any patient has any three of these he has metabolic syndrome.

\section{Ethical approval:}

An approval of the study was obtained from Zagazig Unive rsity academic and ethical committee. Every patient signed an informed written consent for acceptance of the operation. This work has been carried out in accordance with The Code ofEthics of the World Medical Association (Declaration of Helsinki) for studies involving humans.

\section{Statistical analysis:}

Recorded data were analyzed using the statistical package for social sciences, version 20.0 (SPSS Inc., Chicago, Illinois, USA). Quantitative data were expressed as mean \pm standard deviation (SD). Qualitative data were expressed as frequency and percentage. Independentsamples t-test of significance was used when comparing between two means. Chi-square $\left(\mathrm{x}^{2}\right)$ test of significance was used in order to compare proportions between qualitative parameters. The confidence interval was set to $95 \%$ and the margin of error accepted was set to $5 \%$. So, the p-value was considered significant as the following: Probability (P-value): $\mathrm{P}$-value $\leq 0.05$ was considered significant. $\mathrm{P}$-value $<0.001$ was considered as highly significant. P-value $>0.05$ was considered insignificant.

\section{RESULTS}

The mean age of the patients was $42.03 \pm 10.93$ years (range 19-80 years). There were 32 (40\%) females and $48(60 \%)$ males (Table 1$)$.

Table (2) showed that HTN was 46(57.5\%), DM was 31 (38.8\%), Dyslipidemia was 31 (38.8\%), Family history of HTN was $40(50.0 \%)$, Family history of CVS was $41(51.3 \%)$, Family history of DM was $46(57.5 \%)$ and CVS disease was $56(70.0 \%)$

Table (3) showed that the CMV IgG was 78 (97.5\%), CMV IgM was $11(13.8 \%)$ and combined CMV IgG and IgM was (12.5\%) of CMV.

Table (4) showed that the metabolic syndrome was $85 \%$ and non-metabolic syndrome was $15 \%$.

There was no statistically significant difference between metabolic syndrome and non- metabolic syndrome regarding demographic data (Table 5). 
Table (6) showed statistically significant difference between metabolic syndrome and non-metabolic syndrome concerning CMV IgG.

Table (1): Distribution of haemodialysis patients according to their demographic data regarding sex and age $(\mathrm{n}=80)$

\begin{tabular}{|l|c|}
\hline Demographic data & Total $(\mathbf{n = 8 0})$ \\
\hline Sex & \\
Female & $32(40.0 \%)$ \\
Male & $48(60.0 \%)$ \\
\hline Age (years) & $19-80$ \\
Range & $42.03 \pm 10.93$ \\
Mean \pm SD & \\
\hline
\end{tabular}

Table (2): Distribution of haemodialysis patients according to their history $(\mathrm{n}=80)$

\begin{tabular}{|l|c|}
\hline History & Total $(\mathbf{n = 8 0})$ \\
\hline HTN & $46(57.5 \%)$ \\
\hline DM & $31(38.8 \%)$ \\
\hline Dyslipidemia & $31(38.8 \%)$ \\
\hline Family history of HTN & $40(50.0 \%)$ \\
\hline Family history of CVS & $41(51.3 \%)$ \\
\hline Family history of DM & $46(57.5 \%)$ \\
\hline CVS disease & $56(70.0 \%)$ \\
\hline
\end{tabular}

Table (3): Distribution of haemodialysis patients according to their CMV $(\mathrm{n}=80)$

\begin{tabular}{|l|c|}
\hline CMV & Total $(\mathbf{n = 8 0})$ \\
\hline CMV IgG & $78(97.5 \%)$ \\
\hline CMV IgM & $11(13.8 \%)$ \\
\hline Combined CMV IgG and IgM & $10(12.5 \%)$ \\
\hline
\end{tabular}

Table (4): Distribution of haemodialysis patients according to their metabolic syndrome $(n=80)$

\begin{tabular}{|l|c|}
\hline Me tabolic Syndrome & Total $(\mathbf{n = 8 0})$ \\
\hline Metabolic syndrome & $68(85.0 \%)$ \\
\hline Non-metabolic syndrome & $12(15.0 \%)$ \\
\hline
\end{tabular}

Table (5): Comparison between metabolic syndrome and non-metabolic syndrome according to demographic data

\begin{tabular}{|c|c|c|c|c|}
\hline $\begin{array}{l}\text { Demographic } \\
\text { data }\end{array}$ & $\begin{array}{c}\text { Me tabolic } \\
\text { syndrome } \\
(\mathrm{n}=68)\end{array}$ & $\begin{array}{c}\text { Non } \\
\text { metabolic } \\
\text { syndrome } \\
(n=12)\end{array}$ & $t / \mathbf{x} 2 \#$ & p-value \\
\hline \multicolumn{5}{|l|}{ Sex } \\
\hline Female & $\begin{array}{c}28 \\
(41.2 \%)\end{array}$ & $\begin{array}{c}4 \\
(33.3 \%)\end{array}$ & \multirow{2}{*}{$0.261 \#$} & \multirow{2}{*}{0.609} \\
\hline Male & $\begin{array}{c}40 \\
(58.8 \%)\end{array}$ & $\begin{array}{c}8 \\
(66.7 \%)\end{array}$ & & \\
\hline \multicolumn{5}{|l|}{ Age (years) } \\
\hline Mean \pm SD & $\begin{array}{c}42.51 \pm \\
10.59\end{array}$ & $\begin{array}{c}39.25 \pm \\
12.89\end{array}$ & 0.908 & 0.344 \\
\hline
\end{tabular}

$t$-Independent Sample t-test; $\# x^{2}:$ Chi-square test; $p$ value $>0.05 \mathrm{NS}$
Table (6): Comparison between metabolic syndrome and non-metabolic syndrome according to CMV

\begin{tabular}{|c|c|c|c|c|}
\hline CMV & $\begin{array}{l}\text { Me tabolic } \\
\text { syndrome } \\
(n=68)\end{array}$ & \begin{tabular}{|c} 
Non \\
metabolic \\
syndrome \\
$(n=12)$
\end{tabular} & $\mathbf{x} 2$ & p-value \\
\hline \multicolumn{5}{|c|}{ CMVIgG } \\
\hline Positive & $\begin{array}{c}68 \\
(100.0 \%)\end{array}$ & $\begin{array}{c}10 \\
(83.3 \%)\end{array}$ & \multirow{2}{*}{11.624} & \multirow{2}{*}{$<0.001 * *$} \\
\hline Negative & $0(0.0 \%)$ & $\begin{array}{c}2 \\
(16.7 \%)\end{array}$ & & \\
\hline \multicolumn{5}{|c|}{ CMV IgM } \\
\hline Positive & $\begin{array}{c}10 \\
(14.7 \%)\end{array}$ & $1(8.3 \%)$ & \multirow{2}{*}{0.349} & \multirow{2}{*}{0.555} \\
\hline Negative & $\begin{array}{c}58 \\
(85.3 \%)\end{array}$ & $\begin{array}{c}11 \\
(91.7 \%)\end{array}$ & & \\
\hline $\begin{array}{l}\text { Positive } \\
\text { CMV } \\
\text { IgG + } \\
\text { IgM }\end{array}$ & $\begin{array}{c}10 \\
(14.7 \%)\end{array}$ & $0(0.0 \%)$ & 2.017 & 0.156 \\
\hline
\end{tabular}

\section{DISCUSSION}

The age of these patients ranged from 19 to 80 years old with mean $42.03 \pm 10.93$ years $(\mathrm{SD})$ including forty-eight (48) males (60\%) and thirty-two (32) females $(40 \%)$.

Patients who had cardiovascular disease were 56 (70\%), hypertension were $46(57.5 \%)$, DM were 31 $(38.8 \%)$ and dyslipidaemia were 31 (38.8\%).

To achieve the aim of the study we took patients' history including their family history and they were clinically examined for signs of metabolic syndrome components according to AHA/NHLBI and IDF cut points for Middle East ethnicity. Moreover, they were laboratory investigated for CMV IgG and IgM, lipid profile, fasting plasma glucose, inflammation markers, kidney function tests, liver enzymes and uric acid level. Results of our study are in line with our research hypothesis and confirm it.

In the present study, we divided the patients into three groups, first group 78 patients were positive for CMV IgG (97.5\%), second group 11 patients were positive for CMV $\operatorname{IgM}(13.8 \%)$ and third group 10 patients were positive for both $\operatorname{IgG}$ and $\operatorname{IgM}(12.3 \%)$.

We found that there was a statistical significance difference between males and females according to positive CMV IgM and positive both IgG and IgM. This is in accordance with Ocak et $\boldsymbol{a l}$. (10) who aimed to investigate the seroprevalence of CMV infection among the HD patients. Serum samples were taken from 255 patients who received treatment in 3 different $\mathrm{HD}$ clinics. Positivity for anti-CMV IgG was found in 254 (99.6\%) of the 255 HD patients. Many other studies around the World confirmed our result of high prevalence of CMV antibodies in hemodialysis patients with rang from $60 \%$ to $99 \%$. this difference may be due to that, seropositivity of CMV is controlled by socioeconomic levels, age, race and gender ${ }^{(\mathbf{1 1})}$. 
The fact that our findings vary by gender, in our study the females had more CMV antibodies. That variety is interesting but not unfounded. It's well established that the immune response differs between males and females in terms susceptibility to infection and disease progression, with females generally exhibiting higher antibody production and lower levels of inflammations in response to infection ${ }^{(12)}$. It is likely that estrogens in females and androgens in males play a role in giving rise to the gender discrepancies seen in $\mathrm{CMV}^{(\mathbf{1 3})}$. Alternatively, such differences may simply a result of females being re-infected more often than males. Indeed, females are more likely to be seropositive to CMV in general, as well as have higher CMV antibody titers once infected ${ }^{(14)}$. Primary CMV infection does not protect against future re-infection. Gender differences in host immunometabolic responses have also been reported for a variety of other viral infections, including $\mathrm{HCV}{ }^{(15)}, \mathrm{HIV}{ }^{(16)}$, and dengue virus ${ }^{(17)}$.

In the present study, patients were divided according to AHA /NHLBI guidelines and IDF cut points of WC Alberti et al. ${ }^{(8)}$ into two groups, first one was patients with metabolic syndrome $(68,85 \%)$ and second group was patients without metabolic syndrome $(12,15 \%)$. We used the IDF waist circumference measurement cut points for Middle East. This is in accordance with the Egyptian study that confirmed the high rate of metabolic syndrome in middle-aged and elderly Egyptians, which was 55\% of whole sample using ATP 111 guidelines ${ }^{\left({ }^{18}\right)}$. The higher rate of our study can be explained by that we used different updated guidelines and specific waist circumference cut points for Middle East population and our study sample was hemodialysis patients who were immunocompromised. Previous studies reported metabolic syndrome in 40 to $60 \%$ of HD patients ${ }^{(19)}$.

In our study patients who had MetS and CMV IgG were 68 (100\%). The relationship between MetS and CMV IgG is statistically proved. Contre ras et al. (20) agree with our result. They suggest that the cause of this relation between CMV infection and metabolic syndrome in mice is that CMV infection site in adipose tissue is leading to sustained and lifelong adaptive immune response mediated by $\mathrm{CD} 8 \mathrm{~T}$ cells that correlates with hyperglycaemia.

\section{CONCLUSION}

It is important to of early investigate for metabolic syndrome components especially in patients who are immunocompromised like HD patients because of the high prevalence of both chronic CMV infection and reactivation.

\section{REFERENCES}

1. Center for Disease Control and Prevention (2019): Chronic kidney disease surveillance system. https://www.niddk.nih.gov/health-information/healthstatistics/kidney-disease

2. Goodrum F (2016): Human Cytomegalovirus Latency: Approaching the Gordian Knot. Annu Rev Virol., 3: 333-357.

3. Loewendorf A, Benedict C (2010): Modulation of host innate and adaptive immune defenses by cytomegalovirus: timing is every thing. J Intern Med., 267: 483-501.

4. Munks M, Cho K, Pinto A et al. (2006): Four distinct patterns of memory CD8 T cell responses to chronic murine cytomegalovirus infection. J Immunol., 177: 450-8.

5. Wertheimer A, Bennett M, Park B (2014): Aging and cytomegalovirus infection differentially and jointly affect distinct circulating $T$ cell subsets in humans. J Immunol NIH Public Access, 192: 2143-55.

6. Olufadi R, Byrne C (2008): Clinical and laboratory diagnosis of the metabolic syndrome. J Clin Pathol., 61 (6): 697-706.

7. Grundy S, Cleeman J, Daniels S (2005): Diagnosis and management of the metabolic syndrome: an American Heart Association/National Heart, Lung, and Blood Institute Scientific Statement. Circulation, 112 (17): 2735-52.

8. Alberti K, Eckel R, Grundy S et al. (2009): Harmonizing the metabolic syndrome: a joint interim statement of the International Diabetes Federation Task Force on Epidemiology and Prevention; National Heart, Lung, and Blood Institute; American Heart Association; World Heart Federation; International Atherosclerosis Society; and International Association for the Study of Obesity. Circulation, 120 (16): 1640-5.

9. Kraat Y, Hendrix M, Landini M et al. (1992): Comparison of four techniques for detection of antibodies to CMV. Journal of Clinical Microbiology, 30: 522-4.

10. Ocak S, Zeteroglu S, Ozer C et al. (2007): Seroprevalence of Toxoplasma gondii, rubella and cytomegalovirus among pregnant women in southern Turkey. Scand J Infect Dis., 39 (3): 231-4.

11. Nabipour I, Vahdat $K$, Jafari $S$ et al. (2006): The association of metabolic syndrome and Chlamydia pneumoniae, Helicobacter pylori, cytomegalovirus, and herpes simplex virus type 1: the Persian Gulf Healthy Heart Study. Cardiovasc Diabetol., 5: 25-32.

12. Oertelt-Prigione $S$ (2012): The influence of sex and gender on the immune response. Autoimmun Rev., 11 (6-7): 479-85.

13. Terrazzini N, Bajwa M, Thomas D et al. (2014): Gender differences and age-specific associations between body mass index and other cardiovascular risk factors in $\mathrm{CMV}$ infected and uninfected people. Immunol Lett., 162 (1 Pt B): 316-22.

14. Bate S, Dollard S, Cannon M (2010): Cytomegalovirus seroprevalence in the United States: the national health and nutrition examination surveys, 1988-2004. Clin Infect Dis., 50 (11): $1439-47$.

15. Lao X, Thompson A, McHutchison J et al. (2011): Sex and age differences in lipid response to chronic infection with the hepatitis $\mathrm{C}$ virus in the United States National Health and Nutrition Examination Surveys. J Viral Hepat., 18 (8): 571-9.

16. Visnegarwala $F$, Raghavan $S$, Mullin $C$ et al. (2005): Sex differences in the associations of HIV disease characteristics and body composition in antiretroviral-naive persons. Am J Clin Nutr., 82 (4): 850-6.

17. Shahfiza N, Osman H, Hock $T$ et al. (2015): Metabolomics for characterization of gender differences in patients infected with dengue virus. Asian Pac J Trop Med., 8(6):451-6.

18. Abd Elaziz K, Gabal M, Aldafrawy O et al. (2015): Prevalence of metabolic syndrome and cardiovascular risk factors among voluntary screened middle-aged and elderly Egyptians. J Public Health (Oxf), 37 (4): 612-7.

19. Ucar E, Huzmeli C, Guven $O$ et al. (2009): Frequency of metabolic syndrome among hemodialysis patients according to NCEP-ATP III and IDF definitions. Ren Fail., 31 (3): 221-8.

20. Contreras N, Sitnik K, Jeftic I et al. (2019): Life-long control of cy tomegalovirus (CMV) by T resident memory cells in the adipose tissue results in inflammation and hyperglycemia. PLoS Pathog., 15 (6): 7890-96. 